DOI : 10.24260/khatulistiwa.v9i1.1299

\title{
PRINCIPAL POLICY IN DEVELOPING ISLAMIC STUDENT CHARACTERS
}

Ahmad Tanzeh

IAIN Tulungagung, tanzeh@yahoo.co.id

Imam Junaris

IAIN Tulungagung, im02juna@gmail.com

\section{HIGHLIGH}

- The principal can developing policy through several steps; formulating the school's vision and mission, school meetings, formulating policies regarding character values, setting standards for the development of students religious character education.

- The evaluation of principal policies carried out structurally, namely carrying in the board of teachers and staff meetings in weekly, monthly, or every semester.

\begin{tabular}{|c|c|c|}
\hline \multicolumn{3}{|c|}{ ARTICLE HISTORY } \\
\hline Submitt & $:$ & 05 Mar 2019 \\
\hline Revision & : & 10 Mar 2019 \\
\hline $\begin{array}{l}\text { Revision } \\
\text { Minor }\end{array}$ & : & 15 Mar 2019 \\
\hline Accepted & : & 20 Mar 2019 \\
\hline Published & : & 30 Mar 2019 \\
\hline
\end{tabular}

Keyword : $\quad$ Policy, leadership, Islamic character
KHATULISTIWA: Journal of Islamic Studies Vol. 9, No. 1. March 2019

\begin{abstract}
A principal has an important role in establishing student character because a principal is authorized to put policies and rules related to the development of educational institutions. The principal rule is to lead, to guide and to counsel the teachers and staff, so that they can carry out their duties properly. The teacher as an educator and facilitator is an extension of the principal in developing student character. The phenomenon of juvenile delinquency occurred recently is a proof that at this time the spiritual mentality of young generation still weak. Therefore, it is very important to encourage religious values, character and cultural building to the students at the early stage/age.
\end{abstract}

\section{(C2019 Khatulistiwa All Rights Reserved}

DOI: $10.24260 /$ khatulistiwa.v9i1.1299

Principal Policy in Developing Islamic Student

Characters 


\section{A. INTRODUCTION}

Schools are formal institutions that duties are achieving institutional goals which the implications is for achieving national education goals. An important role in the success of school to achieve its objectives is a principal. Principal play an important role in the development of educational institutions. This is in line with Mulyasa opinion that, principal have an important role in coordinating, mobilizing and matching all available educational resources in the school. Principal leadership is one of the main factors that supports the achievement of the school vision, mission, goals and objectives through planned and gradual programs (Mulyasa, 2003)

Related to the principal leadership, it can be said that whether national education goals are achieved or not, the principal must have the proper policies to make the students can actively develop their own potential skills, noble character, intelligence, personality, selfcontrol and religious spiritual strength needed by themselves and community, so that they become people in character, It depends on the principal policy. The phenomenon of juvenile delinquency occurred recently is a proof that at this time the spiritual mentality of young generation is still very weak, so it is very important to build religious values, character and cultural building to the students at the very early age. Student character development can be done through curriculum 2013 which has been echoed by the Ministry of Education and also through the daily habits in schools that students are expected to have a better competence in attitude, skills, knowledge and the students will be more creative, innovative and productive. So that, they will be successful and easy in facing various problems and challenges in their time of obtaining a better future.

Student character development can be occurred through cultured religious values habit and behaviors in the school. When a habituation is practically used, it will become a habit for those who practice it, soon it will become a tradition that is difficult to leave. This habituation pattern applies to all matters even it has good or bad values. Therefore, the school institution is obligated to establish a practice of habituation in a school environment that is programmed both in terms of religious or social values, because if it is not a religious and social habituation, bad habits will be embedded in students.

\section{Principal Policy}

Before explaining the holistic meaning of principal policy, first of all, the researcher explained the meaning of policy. According to Imron, wisdom is a leader provision which is different from the existing rules imposed on someone because of acceptable reasons to not apply the existing rules (Ariesandi, 2006). While according to Gamage and Pang, as quoted by Syafaruddin explained the policy consists of statements about objectives and one or more widely guidelines to achieve the goals so that it can be achieved jointly and provide a framework for implementing the program (Novan, 2012). Furthermore, the meaning of policy in other opinion as stated by Klein and Murphy in Syafaruddin, policy is "a set of goals, principles and regulations that guide an organization, thus policy includes the overall direction of the organization" (Zaitun).

KHATULISTIWA: Journal of Islamic Studies Vol. 9, No. 1. March 2019
DOI: 10.24260/khatulistiwa.v9i1.1299 Principal Policy in Developing Islamic Student Characters 
From the description above, principal policy can be interpreted as the results of decisions made wisely and discreetly for a person/group of people to achieve the desired goal by moving forward into the future. A principal has responsibility for implementing the national education policy set by government. Therefore, the principal has fully responsibility for the school he leads. The principal is the success key of institution he leads. The principal is a leader who brings his institution towards the goals to be achieved by his institution. The success of the principal is seen from his ability to understand the school condition as a unique and complex organization and his ability to carry out the responsibilities entrusted to him.

Besides that, the principal in his role as a leader is required to be able to make effective policy. In the field of education, policies can be grouped into four types, namely; First, policies relating to essential functions such as curriculum, goal setting, recruitment, and student admission. Second, policies regarding individual institutions and the entire education system. Third, policies relating to recruitment, and withdrawal of labor, promotion, supervision, and overall replacement of staff. Fourth, policies relating to the allocation of non-human resources such as financial resources, buildings and equipment. The principal must know what problems are in the school in order to find effective and efficient solutions to the problem.

\section{Development of Student Islamic Characters}

Character is a mental quality, moral, akhlaq, or character of a person who becomes a particular personality as a supporter, driver, and distinguisher from others. Related to the development of the children character, the effort to educate children must be adapted to the world, and also adapted to the growth and development of child. This education can be carried out through education in the family, schools, and children social environment.

Family is the first world that children encounter and experience. Therefore, parents have a very important role in forming children character. Religious education is the most important education that must be taught and grown to the children from an early age. As an element of essence in the human personality religious education can provide a positive role in. the journey of human life. Religious education acts as a behavior manager and controller or actions that are born of a desire based on emotion. If religious education is accustomed as a guideline in daily life and has been grown since an early age, then the behavior will be more managed and controlled.

Furthermore, character education in schools can be carried out with four integrated strategies. First, integrating character education into all subjects. Second, integrating character education into daily activities at school. Third, integrating character education into programmed or planned activities. Fourth, build communication between schools with student parents (Novan, 2012). In addition to the four strategies, of course there are other strategies that can be applied in building and developing students who have commendable character.

From some experts, it is said that the character is identified with morals. Morals can be formed by habituation methods and growth of awareness in the individual, even though initially students refuse or forced to do a good deed or morality, but after a long period of

KHATULISTIWA: Journal of Islamic Studies Vol. 9, No. 1. March 2019
DOI: 10.24260/khatulistiwa.v9i1.1299

Principal Policy in Developing Islamic Student

Characters 
practice, constantly the students are accustomed to by understanding the importance of worship they do, so it will become a good character imprinted on them (Zubaiedi, 2011).

Pavlov, as quoted by Zubaidi, explained that in order to generate or produce the desired reaction called a response, it is necessary to have a stimulus carried out repeatedly called habituation. With the provision of accustomed stimulus, it will lead to an accustomed response. Furthermore, Thorndike said that to get good results, we need training. The training mentioned is an exercise carried out repeatedly in the right and regular order. This theory refers to a system of "trial and error", which is an activity that if we fail we must continue to try again to reach the success (Zubaiedi, 2011).

\section{B. METHOD}

This research use library research. Library research is argumentative disclosure from data sources in the form of studies. Data sources of this study is in the form of books related to the theory or concept of principal policy and student Islamic character development. The other sources are research findings, discussion results, seminars, and so on. The library materials are then discussed and analyzed critically and deeply in order to support propositions and ideas (Tim Penyusun Pedoman UNM, Malang, 2000).

Data collection in this study uses documentation techniques, searching data or theory relevant to the research questions, namely; how is the policy making process of the principal in developing the character of students, how do school citizens implement the principal's policies, and how is the evaluation of the principal's policy in developing student character in the form of notes, books, reports on research findings, scientific articles, journals and so on. After the data is collected then the data is analyzed. The analytical method used is content analysis. Content analysis or content review according to Moleong is a useful analytical technique uses content documents (Lexy J Moleong, 1989) Beside using content studies, the researcher also uses the discussion method with deductive and inductive methods.

\section{RESULT AND DISCUSSION}

The principal policy making in developing the studens character is begun with the school vision and mission formulation, planning the program at the beginning of school year, and formulating policies regarding the character values developed.

\section{a. Formulating the school vision and mission}

Before determining a policy, the school vision and mission must be determined first, then a policy accordance with the school vision and mission will be realized. Vision leads to the formation of a self-image of an organization or school. It is a moral bonding. Mission is an interpretation of a school vision that is implemented in short and long term activity plans. So, the mission is the desire of the organization in the future. It means that the mission directs the school and its members towards the coveted image of the organization. And it should be noted that the main purpose of all activities is worship (Imron Muttaqin, 2018).

Some steps taken by the principal in determining a policy, namely: a). Agenda

arrangement on the education agenda, b). Policy formulation, namely formulating alternative

KHATULISTIWA: Journal of Islamic Studies

Vol. 9, No. 1. March 2019
DOI: 10.24260/khatulistiwa.v9i1.1299

Principal Policy in Developing Islamic Student

Characters 
policies to overcome problems, c). Adoption of policies, namely alternative policies are adopted/taken for solutions in solving the problem, d). Policy implementation, namely the policies that have been taken implemented in education, e). Policy assessment, namely this stage of the assessment stage in policy making and achievement of objectives in education policy (Syafaruddin, 2008).

Principal as policy makers should view the student character development as necessary to realize the school's vision and mission, and determine policies for the development of student character based on the vision and mission that has been formulated. This is in accordance with the theory of Gamage and Pang as quoted by Syafaruddin, namely: "policy consists of statements about objectives and one or more broad guidelines to achieve these goals so that they can be achieved jointly and provide a framework for implementing the program" (Syafaruddin, 2008).

\section{b. School Meeting}

In determining the character development policy of principal as policy makers, it does not mean principal decide his own policies, but it always carried out through programmed meetings. The meeting to determine the character development policy was carried out at the beginning of school year because of planning activities for the next year is also through the previous year evaluation of the student activity report book recapitulation and input suggestions from foster parents through homeroom teacher. This is in line with what was conveyed by Burhanudin, namely "The principal policy is the result of decisions made wisely and discreetly by the principal for someone/group of people to achieve the desired goals by moving forward into the future" (Burhanuddin, 1994).

So, the annually, weekly, monthly meetings conducted by the principal with the board of teachers and staffs are a step taken by the principal in determining policies wisely and discreetly by consulting with the board of teachers so that the objectives of policy can be carried out well.

\section{c. Policy Formulation Regarding Character Values.}

In formulating a policy regarding what character values to be developed by the principal must be based on the school vision and mission. The religious values developed essentially refer to iman (faith), taqwa (god-fearing) and akhlakul karimah (Islamic attitudes) as in the school vision and mission. According to Zaitun and Habibah explained that the implementation of character education in schools can be achieved at least through four integrated alternative strategies. The four strategies are (1) integrating character education with all subjects, (2) integrating character education into daily activities in schools, (3) integrating character education into each activity program, and (4) building communication between schools and foster parents.

\section{d. Establishment of standards for the development of student religious character education}

KHATULISTIWA: Journal of Islamic Studies Vol. 9, No. 1. March 2019
DOI: 10.24260/khatulistiwa.v9i1.1299

Principal Policy in Developing Islamic Student

Characters 
The standard of character development is a standard of achievement obtained by students, for example students are able to memorize letters of yasin (in religious habitual activities), students are skilled in communicating with good, correct, and polite language with teachers or friends. Van Meter and Van Horn said that standards and target policies must be clear and measurable so that they can be realized. If the standard and policy objectives are not clear, there will be multiple interpretations and it will be easy to cause conflict between doer as implementers (Forester, 2008).

\section{e. Formulation of school rules}

Generally school discipline can be interpreted as a bond or rule that must be followed by every school citizen. The implementation will run well if all school members support each other in implementing the rules. In this case, principal, teachers, staff, and students must be fully involved and support the implementation of agreed school rules for the realization of a school environment that supports the expected students character development.

School discipline is a collection of written rules that are morally binding on all school members so that the education process can be carried out effectively and efficiently. This is in line with Meichati as quoted by Marliana and Yani who stated that "Rule is set of order that bind a person or group, to create their own security and peace" (Ayu Diyah Maulana, 2013).

\section{School citizen engagement in implementing the principal policy of developing Islamic character.}

In developing student character, policies taken by school principals can be carried out by applying habituation in giving exemplary and involving all school members intensively and consistently in daily, weekly, monthly, or incidentally.

\section{a. Applying habituation}

Habituation is the main principal in developing student character, both characters that need to be instilled in school, at home or in the environment where they live, values of spiritual character, discipline, responsibility and mutual cooperation that are developed and understood well. With the habituation carried out by individuals, it will make the individual faster to understand the character values developed including memorizing short surah, surah yasin, dhuha prayers and dhuhur prayers in congregation, Friday charity, communicating with friends or teachers using good and right language, keeping clean, having school discipline, smiling and greetings, and shaking hand politely when they meet the teacher. In the practice of habituation, principal need effective communication as interprofesionalcollaborative communication, associative and interpersonal communication (Imron Muttaqin, 2018). In the behaviorist view, student behavior can be formed through habituation (operant conditioning). Habit is an effective way of implementing student character development. Habits will make students able to carry out things lightly without enforcement. Good habits that are instilled since childhood, will be a character that is difficult to change when they are an adult. Therefore good habits must be instilled since the child is in elementary school even since they were child.

KHATULISTIWA: Journal of Islamic Studies Vol. 9, No. 1. March 2019
DOI: 10.24260/khatulistiwa.v9i1.1299

Principal Policy in Developing Islamic Student

Characters 
Pavlov, as quoted by Zubaiedi, stated that to rise or produce a desired reaction called a response, so it is necessary to have a stimulus carried out repeatedly so that it is called habituation. With the provision of accustomed stimulus, it will lead to an accustomed response (Zubaiedi, 2011). This is in line with Thorndike who mentioned that in order to get good results we need training. The training is an exercise carried out repeatedly, regularly, and orderly.

\section{b. Giving exemplary}

Students not only need advice and orders, but also examples. Students need more direct examples from the teacher about the good behavior they must do. If the teachers do something good, then without being instructed students will follow what the teacher exemplified. For example, if the teacher is disciplined, polite, and respects others, then students will follow the kindness done by the teacher. Tafsir said that the strategies that can be carried out by education practitioners in forming religious culture in schools including giving exemplary exemplified by principal and teachers (Ahmad Tafsir, 2004).

\section{Evaluation of Principal Policy in Developing Islamic Student Characters a. Structured evaluation}

The evaluation of character development policies can be carried out structurally in the meetings of teachers and employees weekly, monthly, or each semester through the results of student exams related to religious activities and recapitulation of student activity report books. Evaluation or assessment is carried out as control or supervision of activities or policies taken by principal. Terry as quoted by Marno and Supriyanto stated that control is a form of business to see activities that will and have been carried out to assess the success of a program. Meanwhile, Konntz \& O'Donnel means that control or supervision is the measurement and improvement of the implementation of subordinate work so that the plans that have been made to achieve organizational goals can be carried out properly (Marno, 2008).

In line with those view, Shulhan said that control or supervision is an activity to measure the effectiveness of personnel work and the level of efficiency of the certain methods and tools implementation used to achieve goals (Muwahid Shulhan, 2005). Control or supervision is an activity to measure and examine also correct the implementation of a plan that has been prepared to run effectively. Supervision is a decisive step towards what must be carried out, while managing and improving, so that the implementation is in accordance with the plan, and realized effectively and efficiently.

b. Incidental evaluation

Incidental evaluations are carried out accordance with needs and directly, for example the principal or teacher finds the problem of habituating good and correct language toward friends which is not carried out by students, at that time the principal or teacher as students assistant provides guidance to students. The way to make an assessment can be carried out

by comparing what has been done with a criterion, evaluators can directly compare with the

KHATULISTIWA: Journal of Islamic Studies Vol. 9, No. 1. March 2019
DOI: 10.24260/khatulistiwa.v9i1.1299

Principal Policy in Developing Islamic Student

Characters 
criteria but it can also measure something that is evaluated and then compare it to the criteria. Thus evaluation is not always through a new process of measuring the assessing process but it can also be directly evaluated through assessment. A similar view was expressed by Crawford as quoted by Arikunto and Jabar which interpreted assessment as a process to find out or test whether an activity, activity process, and a program output were in accordance with the objectives or criteria that have been determined (Suharsimi Arikunto, 2004).

\section{CONCLUSION}

The principal can run several steps through; formulating the school's vision and mission, school meetings, formulating policies regarding character values, setting standards for the development of students religious character education, and formulating school rules relating to the character developed.

The school citizen engagement to carry out the principal policies in developing students Islamic character, the policies taken by principal can be carried out by applying habituation of giving exemplary and involving all school citizen intensively and consistently in daily, weekly, monthly or incidentally.

The evaluation of principal policies in developing students character is carried out structurally, namely carrying in the board of teachers and staff meetings in weekly, monthly, or every semester through the result of students exam related to religious activity and report book recapitulation of student activities. Then, the evaluation is carried out incidentally and directly, for instance, principal or teacher find habituation problems in applying good and correct language done by the students in communicating with the other students, at that time, the principal or teachers as students assistant give the guidance to the students to use the good and correct language in communicating with their friends.

KHATULISTIWA: Journal of Islamic Studies Vol. 9, No. 1. March 2019
DOI: 10.24260/khatulistiwa.v9i1.1299

Principal Policy in Developing Islamic Student

Characters 


\section{BIBLIOGRAPHY}

Arikunto, Suharsimi \& Jabar (2004). Evaluasi Progrm Pendidikan. Jakarta:Bumi Aksara Burhanuddin (1994). Analisis Administrasi Manajemen dan Kepemimpinan Pendidikan. Jakarta: Bumi Aksara

Forester-Rimbawan, 2018. blogspot.com,Imlementasi Kebijakan publik, accessed on July 23rd, at 22.14 WIB.

Imron, Ali. (2008). Kebijkasanaan Pendidikan di Indonesia Proses, Produk dan Masa Depannya. Jakarta: Bumi Aksara.

Muttaqin, I. (2018). Konsep da Prinsip Manajemen pendidikan Dalam Al-Qur'an. At-Turats, 12(1), 32-49.

Muttaqin, I. (2018). Komunikasi dan Dakwah Pada lembaga Pendidikan Islam. Al-Hikmah, 12(2).

Marliana, Ayu Diyah dan Yani, M. Turhan. 2013. "Strategi Sekolah dalam Menangani Pelanggaran Tata Tertib Sekolah pada Siswa di Smp Negeri I Papar Kediri", Penelitian, Kajian Moral dan Kewarganegaraan No 1 Vol 1 Tahun 2013 Kediri,

Marno dan Supriyanto,Triyo (2008). Manajemen dan Kepemimpinan Pendidikan Islam. Bandung: Reflika Aditama.

Moleong, J. Lexy. (1989). Metodologi Penelitian Kualitatif. Bandung: Remaja Rosda Karya

Mulyasa. E. (2003). Menjadi Kepala Sekolah Professional. Bandung: PT Remaja Rosdakarya Offset

Setyono, Ariesandi. (2006). Hypnoparenting: Menjadi Orangtua Efektif dengan Hipnosis. Jakarta: PT. Gramedia Pustaka Utama

Shulhan, Muwahid. (2005). Administrasi Pendidikan, Surabaya:el.KAF

Syafaruddin. (2008). Efektifitas Kebijakan Pendidikan. Jakarta: Rineka Cipta

Tafsir, Ahmad. (2004). Metodologi Pengajaran Agama Islam. Bandung, PT. Remaja Rosdakarya

Tim Penyusun Universitas Negeri Malang (UM). (2000). Pedoman Penulisan Karya Ilmiah. Malang

Wiyani, Novan Ardi. (2012). Manajemen Pendidikan Karakter; Konsep dan Implementasinya di Sekolah. Yogyakarta: PT Pustaka Insan Madani

KHATULISTIWA: Journal of Islamic Studies Vol. 9, No. 1. March 2019
DOI: 10.24260/khatulistiwa.v9i1.1299

Principal Policy in Developing Islamic Student

Characters 
Zaitun dan Habibah, Siti, Jurnal Pendidikan Agama Islam - Ta'lim Vol 11 No. 2

Zubaiedi. (2011). Desain Pendidikan Karakter: Konsepsi dan Aplikasinya Dalam Lenbaga Pendidikan. Jakarta: Kharisma Putera Utama

DOI: $10.24260 /$ khatulistiwa.v9i1.1299

Principal Policy in Developing Islamic Student Characters 